\title{
Aspect regarding the use of renewable energy into vegetable farms of agritouristic pensions
}

\author{
Oana Bianca Oprea ${ }^{1}$, Cristina Popovici ${ }^{2}$, Liviu Gaceu ${ }^{3}$
}

\section{N F O \\ Received 28 Nov 2014 \\ Accepted 7 Jan 2015 \\ Available on-line 14 Jan 2015 \\ Responsible Editor: M. Herdon}

Keywords:

micro-drip irrigation, vegetable farm, photovoltaic energy

\begin{abstract}
A B S TRACT
The main goal in the agritouristic pension design is that tourists can consume organic plant products produced in the guest house farm or its immediate neighborhood. This paper aims are on one hand to design a vegetable farm based on the necessity of specific products needed for the operation of a medium pension with 9 rooms, and secondly to assess the possibility of using photovoltaic energy for powering the micro-drip irrigation system. Starting from the amount of vegetable needs for tourists from an average agritouristic pension, it was calculated the number of plants, the required surface for the plants and the amount of water needed. Based on daily and monthly needs there were established technical and constructive parameters of the solar drip irrigation installation (diameter and length of hoses, flow, pressure and pump power and solar panel characteristics). The model can be easily adapted to other size pensions or to different climatic conditions.
\end{abstract}

\section{Introduction}

Climate change, coupled with concerns about high oil and energy prices, is driving a global trend towards the increased use of renewable energy. Unlike fossil fuels which are rapidly being depleted, renewable energy sources such as sunlight and wind are naturally replenished and therefore sustainable. Indeed, it is the perceived notion of sustainability that is driving governments around the world to introduce legislation promoting the use of renewable energy. [1]

Agritouristic pensions currently attract an increasing numbers of tourists because of the possibilities to consume organic plant products, acquired in own farms. [9]

Achieving high quality vegetable products require intensive irrigation activity in most parts of Central and S-E of Europe. Therefore, in the particular case of an agritouristic pension with vegetable farm, irrigation is essential for achieving enough vegetable quality to support catering activities.

For economic efficiency of vegetable productions on irrigated land areas, the issue is set on reducing energy consumption, together with the use of renewable energy sources.

Integration of modern drip irrigation while using photovoltaic solar energy to drive the water pump in the vegetable farm of a pension produces effective social and economic challenges

\footnotetext{
${ }^{1}$ Oana Bianca Oprea

Transilvania University of Brasov, Faculty of Food and Tourism, Romania

bianca.oprea@xu.unitbv.ro

${ }^{2}$ Cristina Popovici

Technical University of Moldavia

cristi_smile@mail.ru

${ }^{3}$ Liviu Gaceu

Transilvania University of Brasov, Faculty of Food and Tourism, Romania gaceul@unitbv.ro
} 
by promoting the concept of "Green Economy" to the masses, by reducing costs and increasing the farm independence rank of utility networks in rural areas.

\section{Problem statements}

The study proposed in this paper focuses on designing solar drip irrigation system at a vegetable farm of a pension with a capacity of approx. 18 beds, consisting of 2 single rooms, 5 double rooms and 2 suites. The vegetable farm will be irrigated with a micro-drip irrigation system, water supply being achieved by using a submersible pump powered by a photovoltaic panel.

Calculation method involves the following steps: calculation of raw materials (vegetables) in the kitchen; of ground surface and water quantity needed for each vegetable species; of drip irrigation installation; of the water supply pump; calculation and selection of solar panels.

\subsection{Calculation of raw materials in the pension kitchen}

Considering a suggestion of a menu based on traditional recipes with specific diets rich in vitamins, minerals and natural fibres, it was obtained the final gross amount of raw materials by adding elements used in each preparation, taking into account the losses that occur after cleaning and thermal processes.

Tabel 2.1. Balance of raw materials required for preparing the main menus (required for 1 person /day)

\begin{tabular}{|l|l|l|l|l|l|l|l|l|}
\hline $\begin{array}{l}\text { Vegetables } \\
\text { and fruits }\end{array}$ & Appetizer & Salad & Soup & Main dishes & Steak & Garnish & Desert & Total \\
\hline Potato & $100 \mathrm{~g}$ & $150 \mathrm{~g}$ & $100 \mathrm{~g}$ & 450 & & $800 \mathrm{~g}$ & & $1600 \mathrm{~g}$ \\
\hline Onion & $10 \mathrm{~g}$ & $30 \mathrm{~g}$ & $50 \mathrm{~g}$ & 100 & & $30 \mathrm{~g}$ & & $210 \mathrm{~g}$ \\
\hline Tomato & $160 \mathrm{~g}$ & $160 \mathrm{~g}$ & & $40 \mathrm{~g}$ & & & & $360 \mathrm{~g}$ \\
\hline Eggplant & $500 \mathrm{~g}$ & & & $50 \mathrm{~g}$ & & & & $550 \mathrm{~g}$ \\
\hline Zucchini & & & $30 \mathrm{~g}$ & $30 \mathrm{~g}$ & & & & $60 \mathrm{~g}$ \\
\hline Cucumber & & $50 \mathrm{~g}$ & & & & & & $50 \mathrm{~g}$ \\
\hline Peas & & & & $400 \mathrm{~g}$ & $10 \mathrm{~g}$ & & & $410 \mathrm{~g}$ \\
\hline Salad & & $50 \mathrm{~g}$ & & & & & & $50 \mathrm{~g}$ \\
\hline Pepper & & $15 \mathrm{~g}$ & $20 \mathrm{~g}$ & $20 \mathrm{~g}$ & & $25 \mathrm{~g}$ & & $80 \mathrm{~g}$ \\
\hline Carrot & & & 60 & $40 \mathrm{~g}$ & $10 \mathrm{~g}$ & & & $110 \mathrm{~g}$ \\
\hline Parsley & & & $10 \mathrm{~g}$ & $15 \mathrm{~g}$ & & & & $25 \mathrm{~g}$ \\
\hline Celery & & & $15 \mathrm{~g}$ & & & & & $15 \mathrm{~g}$ \\
\hline Beans & & & $20 \mathrm{~g}$ & & & & & $20 \mathrm{~g}$ \\
\hline Spinach & $150 \mathrm{~g}$ & $100 \mathrm{~g}$ & $150 \mathrm{~g}$ & & & & & $400 \mathrm{~g}$ \\
\hline Mushrooms & $250 \mathrm{~g}$ & & & $60 \mathrm{~g}$ & & & & $310 \mathrm{~g}$ \\
\hline Corn & & & & & $10 \mathrm{~g}$ & & & $10 \mathrm{~g}$ \\
\hline Dill & $3 \mathrm{~g}$ & & $3 \mathrm{~g}$ & & & & & $6 \mathrm{~g}$ \\
\hline Garlic & $10 \mathrm{~g}$ & & & & & & & $10 \mathrm{~g}$ \\
\hline Apple & & & & & & & $300 \mathrm{~g}$ & $300 \mathrm{~g}$ \\
\hline Quince & & & & & & & $150 \mathrm{~g}$ & $150 \mathrm{~g}$ \\
\hline Nuts & & & & & & & $50 \mathrm{~g}$ & $50 \mathrm{~g}$ \\
\hline
\end{tabular}

The menu consists of: 4 types of appetizers; 4 types of salad; 3 types of soups; 4 main dishes; 4 types of steaks; 3 types of garnish; 3 types of desert. In order to obtain the necessary raw materials per day, the 25 menu portions are divided to the daily average client number, namely to 10 . Thus, there was obtained 2.5 items. Next, is calculated:

Daily requirement: $Y=$ Item $\times X \mathrm{~kg}$

(1), where: Item $-2.5 ; \mathrm{X}$ - product.

Monthly requirement: $Z=Y \times 30$

(2), where: Y necessary product/day 
Annual requirement: $W=Z \times 12$

(3) where: Z - Necessary products/month, W -

Necessary products /year;

In table 2.2. is presented synthetically the calculated amount of vegetables needed for: raw materials necessary for the menu - daily, peeled raw materials $\left(2^{\text {nd }}\right.$ column); quantity of raw vegetables (including losses due to initial processing - peeling, seed removal, etc. $3^{\text {rd }}$ column); quantity of raw vegetables - required monthly amount $-4^{\text {th }}$ column; quantity of raw vegetables - required annual amount $-5^{\text {th }}$ column.

In the case of potatoes for example, Pmm = Product mass to use in menu; $\mathrm{L}=$ Loss $\%$; $\mathrm{Rpm}=$ Raw product mass; $\mathrm{Rpm}=\mathrm{Pmm}+\mathrm{L} * \mathrm{Pmm}=\mathrm{Pmm} *(1+\mathrm{L})$

Table 2.2. Overall material balance for pensions cuisine

\begin{tabular}{|c|c|c|c|c|c|}
\hline $\begin{array}{c}\text { Vegetables } \\
\text { and fruits }\end{array}$ & $\begin{array}{c}\text { Required } \\
\text { daily amount } \\
(\mathrm{kg})\end{array}$ & $\begin{array}{c}\text { Percentage losses in } \\
\text { primary processing } \\
(\%)\end{array}$ & $\begin{array}{c}\text { Required daily } \\
\text { raw vegetables }\end{array}$ & $\begin{array}{c}\text { Required } \\
\text { monthly raw } \\
\text { amount }(\mathrm{kg})\end{array}$ & $\begin{array}{c}\text { Annual raw } \\
\text { amount } \\
\text { required (kg) }\end{array}$ \\
\hline Potato & 4 & 15 & 4,6 & 138 & 1656 \\
\hline Onion & 0,5 & 12 & 0,6 & 28,6 & 211,7 \\
\hline Tomato & 0,9 & 5 & 1,68 & 50,4 & 604,8 \\
\hline Eggplant & 1,4 & 20 & 0,195 & 5,85 & 70,2 \\
\hline Zucchini & 0,15 & 30 & 0,06 & 1,87 & 22,5 \\
\hline Cucumber & 0,05 & 25 & 1,21 & 36,3 & 435,6 \\
\hline Peas & 1,1 & 10 & 0,15 & 4,5 & 54 \\
\hline Salad & 0,125 & 20 & 0,088 & 2,64 & 31,7 \\
\hline Pepper & 0,08 & 10 & 0,34375 & 10,3125 & 123,8 \\
\hline Carrot & 0,275 & 25 & 0,07875 & 2,3625 & 28,4 \\
\hline Parsley & 0,063 & 25 & 0,0494 & 1,482 & 17,7 \\
\hline Celery & 0,038 & 30 & 0,055 & 1,65 & 19,8 \\
\hline Beans & 0,05 & 10 & 1,25 & 37,5 & 450 \\
\hline Spinach & 1 & 25 & 0,96875 & 29,0625 & 348,75 \\
\hline Mushrooms & 0,775 & 25 & 0,0275 & 0,825 & 10 \\
\hline Corn & 0,025 & 10 & 0,01875 & 0,5625 & 6,7 \\
\hline Dill & 0,015 & 25 & 0,0305 & 0,915 & 10,9 \\
\hline Garlic & 0,025 & 22 & 0,9525 & 28,575 & 342,9 \\
\hline Apples & 0,75 & 27 & 0,48 & 14,4 & 172,8 \\
\hline Quince & 0,375 & 28 & 0,16875 & 5,0625 & 60,7 \\
\hline Nuts & 0,125 & 35 & & & \\
\hline
\end{tabular}

\subsection{Calculation of the area of land and water requirement for each vegetable species}

Based on the demand of vegetables in the kitchen there are made calculations for each species separately, as following: required annual gross in kitchen, [kg] (Rak); required annual gross in vegetable warehouse, $[\mathrm{kg}]$ (Raw); minimum area required for each species $\left[\mathrm{m}^{2}\right]$ (Amin); adopted surface for each vegetable layer $\left[\mathrm{m}^{2}\right]$ (As); actual production $[\mathrm{kg}]$ (Ap); quantity of water needed for each vegetable species $\left[\mathrm{m}^{3}\right](\mathrm{Q})$. In the table 2.2 it can be established that the needed amount of potato in the kitchen is Rak $=1656 \mathrm{~kg}$. Knowing the average losses during storage $(\mathrm{L}=20 \%)$, results:

$$
\text { Raw }=\operatorname{Rak} x(1+L)=1656 \times(1+0,2)=1987,2 \mathrm{~kg},(4) ;
$$

Knowing Yha $=16000 \mathrm{~kg} / \mathrm{ha}$, it is calculated the minimum area needed for the potato layer:

$$
\text { Amin }=\text { Raw } / \text { Yha } * 10000=1987,2 / 16000 * 10000=1242 m^{2}(5) \text {; }
$$

Adopted area will be $\mathrm{Aa}=1500 \mathrm{~m}^{2}$, respectively a plot with the following size of $30 \mathrm{x} 50$ $\mathrm{m}$; from the adopted area, the actual production (Ap) will be:

$$
A p=A a \times Y h a / 10000=1500 \times 16000 / 10000=2400 \mathrm{~kg}(6) ;
$$


From the table of irrigation rules [5], [6], for potatoes are recommended watering of 600$1000 \mathrm{~m}^{3} /$ ha between April...July. Are chosen monthly irrigations of $600 \mathrm{~m}^{3} / \mathrm{ha}$ in April....May, $300 \mathrm{~m}^{3} /$ ha in June and $150 \mathrm{~m}^{3} /$ ha in July. Therefore the adopted area (Aa), requires a monthly amount of water of: $Q=A a \times I r / 10000=1500 \times 600 / 10000=90 \mathrm{~m}^{3}$ (7) - for April....May;

$$
\begin{aligned}
& Q=\text { Aa } \times \operatorname{Ir} / 10000=1500 \times 300 / 10000=45 \mathrm{~m}^{3}(8)-\text { for June; } \\
& Q=\text { Aa } \times \text { Ir } / 10000=1500 \times 150 / 10000=22,5 \mathrm{~m}^{3}(9) \text {-for July; }
\end{aligned}
$$

Where: Q - Quantity of water needed for each vegetable species, $\left[\mathrm{m}^{3}\right]$; Ir - Irrigation rate, $\left[\mathrm{m}^{3}\right]$. Results from similar calculations made for all the other vegetables, can be found in table no. 2.3. These amounts are averages values, specific for Romanian geo-climate conditions. [2], [7], [8]. 
Table 2.3. Calculation of surface and needed vegetables

\begin{tabular}{|c|c|c|c|c|c|c|c|}
\hline $\begin{array}{l}\text { Vegetables } \\
\text { and fruits }\end{array}$ & $\begin{array}{c}\text { Required annual } \\
\text { gross in kitchen } \\
{[\mathrm{kg}]}\end{array}$ & $\begin{array}{l}\text { Losses during } \\
\text { storage } \%\end{array}$ & $\begin{array}{l}\text { Required annual gross in } \\
\text { vegetable warehouse }[\mathrm{kg}]\end{array}$ & $\begin{array}{l}\text { Yield per } \\
\text { ha }[\mathrm{kg}]\end{array}$ & $\begin{array}{l}\text { Minimum area required } \\
\text { for each species }\left[\mathrm{m}^{2}\right]\end{array}$ & $\begin{array}{l}\text { Adopted surface for each } \\
\text { vegetable layer }\left[\mathrm{m}^{2}\right]\end{array}$ & $\begin{array}{c}\text { Actual } \\
\text { production } \\
{[\mathrm{kg}]}\end{array}$ \\
\hline Potato & 1656 & $20 \%$ & 1987,2 & 16000 & 1242 & $1500(30 \times 50 \mathrm{~m})$ & 2400 \\
\hline Onion & 211,7 & $20 \%$ & 254,0 & 40000 & 63,5 & $80(8 \times 10)$ & 320 \\
\hline Tomato & 340,2 & $30 \%$ & 442,3 & 55000 & 80,4 & $100(10 \times 10)$ & 550 \\
\hline Eggplant & 604,8 & $5 \%$ & 635,0 & 40000 & 158,7 & $180(10 \times 18)$ & 720 \\
\hline Zucchini & 70,2 & $5 \%$ & 73,7 & 20000 & 36,8 & $40(4 \times 10)$ & 80 \\
\hline Cucumber & 22,5 & $35 \%$ & 30,4 & 35000 & 8,7 & $25(5 \times 5)$ & 87,5 \\
\hline Peas & 435,6 & $5 \%$ & 457,4 & 10000 & 457,4 & $460(10 \times 46)$ & 460 \\
\hline Salad & 54 & $15 \%$ & 62,1 & 17000 & 36,5 & $40(4 \times 10)$ & 68 \\
\hline Pepper & 31,7 & $10 \%$ & 34,8 & 34000 & 10,2 & $20(2 \times 10)$ & 68 \\
\hline Carrot & 123,8 & $25 \%$ & 154,7 & 25000 & 61,9 & $64(8 \times 8)$ & 160 \\
\hline Parsley & 28,4 & $15 \%$ & 32,6 & 30000 & 10,8 & $10(2 \times 5)$ & 30 \\
\hline Celery & 17,7 & $20 \%$ & 21,4 & 25000 & 8,5 & $10(2 \times 5)$ & 25 \\
\hline Beans & 19,8 & $5 \%$ & 20,8 & 7000 & 29,7 & $35(5 \times 7)$ & 24,5 \\
\hline Spinach & 450 & $5 \%$ & 472,5 & 22000 & 214,7 & $220(10 \times 22)$ & 484 \\
\hline *Mushrooms & 348,75 & $5 \%$ & 366,1875 & & & & \\
\hline Corn & 10 & $5 \%$ & 10,5 & 3000 & 35 & $35(5 \times 7)$ & 10,5 \\
\hline Dill & 6,7 & $15 \%$ & 7,7 & 20000 & 3,8 & $8(2 \times 4)$ & 17,6 \\
\hline Garlic & 10,9 & $5 \%$ & 11,5 & 5000 & 23 & $25(5 \times 5)$ & 12,5 \\
\hline **Apple & 342,9 & $35 \%$ & 462,9 & 60000 & 13 trees $=\mathbf{7 7 , 1}$ & $80(8 \times 10)$ & \\
\hline **Quince & 172,8 & $30 \%$ & 224,6 & 50000 & 8 trees $=\mathbf{4 4 , 9}$ & $50(5 \times 10)$ & \\
\hline$* * \mathrm{Nut}$ & 60,7 & $10 \%$ & & & 3 trees $=\mathbf{6 0}$ & $18(2 \times 9)$ & \\
\hline Total & & & & & 2663,6 & 3000 & 5517,6 \\
\hline
\end{tabular}

* Mushrooms will be purchased from the nearest mushroom place mushroom farm and are not subject to the calculation of the surface;

$* * 1$ tree $=6 \mathrm{mp}$. Fruit trees do not need extra water for irrigation, the wastewater stored in deep layers at $1-2 \mathrm{~m}$ from the nearby vegetable crops being sufficient. [8].

The amount of water was calculated using data from the table of irrigation rules multiplying the amount required to ha with the number of days in the three months of irrigation Ex. Potato: $400 \mathrm{~m}^{3}$ at 5 days; $90 / 5=18$ days $\mathrm{x} 400 \mathrm{~m}^{3}=7200$. 
Considering the data from the literature [3], for the classical irrigation rules and taking into account the significant reduction in water demand for irrigation by using micro-drip system, for the main vegetables data has been gathered, and it is presented in the table bellow:

Table 2.4. Irrigation rates

\begin{tabular}{|c|c|c|c|c|c|c|c|}
\hline \multirow[b]{2}{*}{ Vegetables } & \multicolumn{7}{|c|}{ Micro-drip irrigation rates (Ir), $\mathrm{m}^{3}$} \\
\hline & March & April & May & June & July & August & $\begin{array}{c}\text { Total } \mathrm{m}^{3} \text { of water/species/whole } \\
\text { period }\end{array}$ \\
\hline Potato & & 90 & 90 & 45 & 22,5 & & 247,5 \\
\hline Onion & 2,4 & 2,4 & 1,2 & 1,2 & & & 7,2 \\
\hline Tomato & 3 & 3 & 1,5 & 1,5 & 0,75 & 0,75 & $\mathbf{1 0 , 5}$ \\
\hline Eggplant & 5,4 & 5,4 & 2,7 & 2,7 & 1,35 & 0,67 & 18,22 \\
\hline Zucchini & 1,2 & 0,6 & & & & & 1,8 \\
\hline Cucumber & 0,75 & 0,75 & 0,75 & 0,37 & 0,37 & 0,18 & 3,17 \\
\hline Peas & & 1,38 & 0,69 & 0,34 & & & 2,41 \\
\hline Salad & & 1,2 & 0,6 & 0,3 & & & 2,1 \\
\hline Pepper & 0,6 & 0,6 & 0,3 & 0,15 & 0,15 & & 1,8 \\
\hline Carrot & 1,92 & 1,92 & 0,96 & 0,48 & & & 5,28 \\
\hline Parsley & 0,3 & 0,15 & 0,07 & & & & $\mathbf{0 , 5 2}$ \\
\hline Celery & & 0,3 & 0,15 & & & & 0,45 \\
\hline Beans & & 1,05 & 0,5 & 0,25 & & & 1,8 \\
\hline Spinach & 6,6 & 3,3 & 1,65 & 0,8 & & & 12,35 \\
\hline Corn & & 1,05 & 0,5 & & & & 1,55 \\
\hline Dill & 0,24 & 0,12 & 0,12 & & & & 0,48 \\
\hline Garlic & 0,75 & 0,37 & & & & & 1,12 \\
\hline Total & 23,16 & 113,59 & 101,69 & 53,09 & 25,12 & 1,6 & 318,25 \\
\hline
\end{tabular}




\subsection{Calculation of micro-drip irrigation installation}

\subsubsection{Calculation of pipelines}

From literature [11], [12], [13], [14] for pipelines with flows of 100-3001/h for lengths of up to $100 \mathrm{~m}$ it is recommended a diameter of $19 \mathrm{~mm}$.

According to image 2.1 there were defined 3 pipelines A, B, C with lengths of $50 \mathrm{~m}$ for: A - potato; B - peas, zucchini, eggplant, tomatoes and spinach; C - salad, onion, pepper, carrot, beans, cucumbers and other spices.

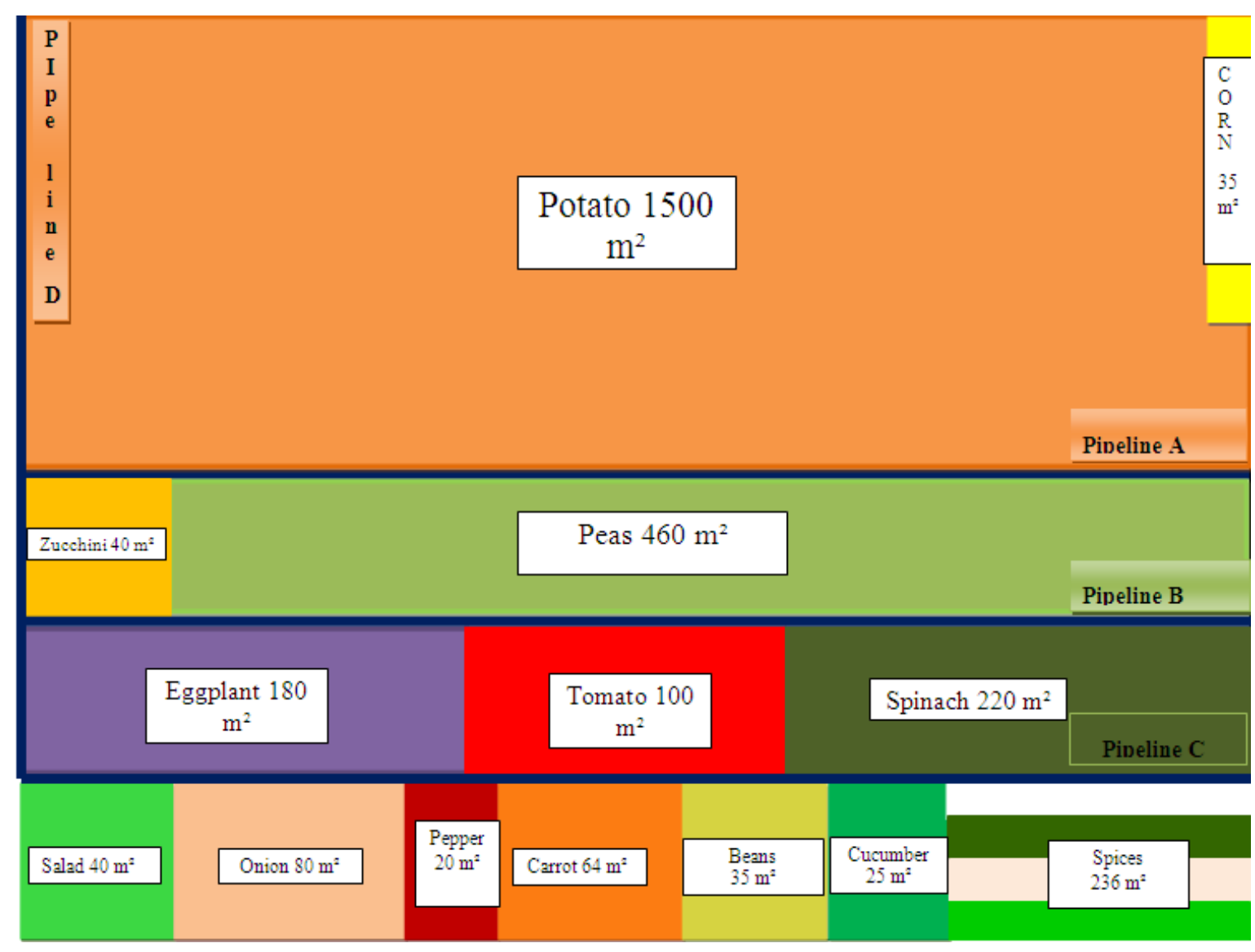

Figure 2.1. Pipelines layout and vegetable layers in the farm

Power for the 3 pipelines $\mathrm{A}, \mathrm{B}$ and $\mathrm{C}$, is made through the $\mathrm{D}$ water pipe with a length of 55 $\mathrm{m}$ and diameter of $55 \mathrm{~mm}$, which is connected to the water tank from the vicinity of the vegetable farm.

\subsubsection{Hose sizing of vegetable layers}

For potato rows, given the distance between two rows must be between 50 and $70 \mathrm{~cm}$, and between nests along the line between $35-50 \mathrm{~cm}$, [13] for a surface of $1500 \mathrm{~m}^{2}$, with a length of $50 \mathrm{~m}$ and width of $30 \mathrm{~m}$, the number of rows (Nrp) is calculated using the formula:

$$
\begin{gathered}
N r p=L / d=50 / 0,5=100 \text { rows }(10), \text { where, } \mathrm{L}=\text { lenght of potato row }-\mathrm{L}=50 \mathrm{~m} ; \mathrm{d}= \\
\text { distance between two rows }- \text { select } \mathrm{d}=0,5 \mathrm{~m} ;
\end{gathered}
$$

Results a number of $3000 \mathrm{~m}$ of hose, 100 connectors and 100 plugs, as shown in the microdrip installation diagram, figure 2.2. The hoses diameter is adopted from the literature, for a 
flow of one $1 / \mathrm{h}$ at a value of $10 \mathrm{~mm}$. The number of potato nests $(\mathrm{Npn})$ will be calculated with the following formula:

$$
\begin{aligned}
N p n=l / d n * N r c a=30 / 0,5 * 100= & 6000 \text { nests }(11), \text { where: } \mathrm{dc}-\text { distance between nests; } 1 \\
& \text { - row width. }
\end{aligned}
$$

In similar ways are made calculations for the other rows of other vegetables and synthesis calculations are presented in table 2.5 .

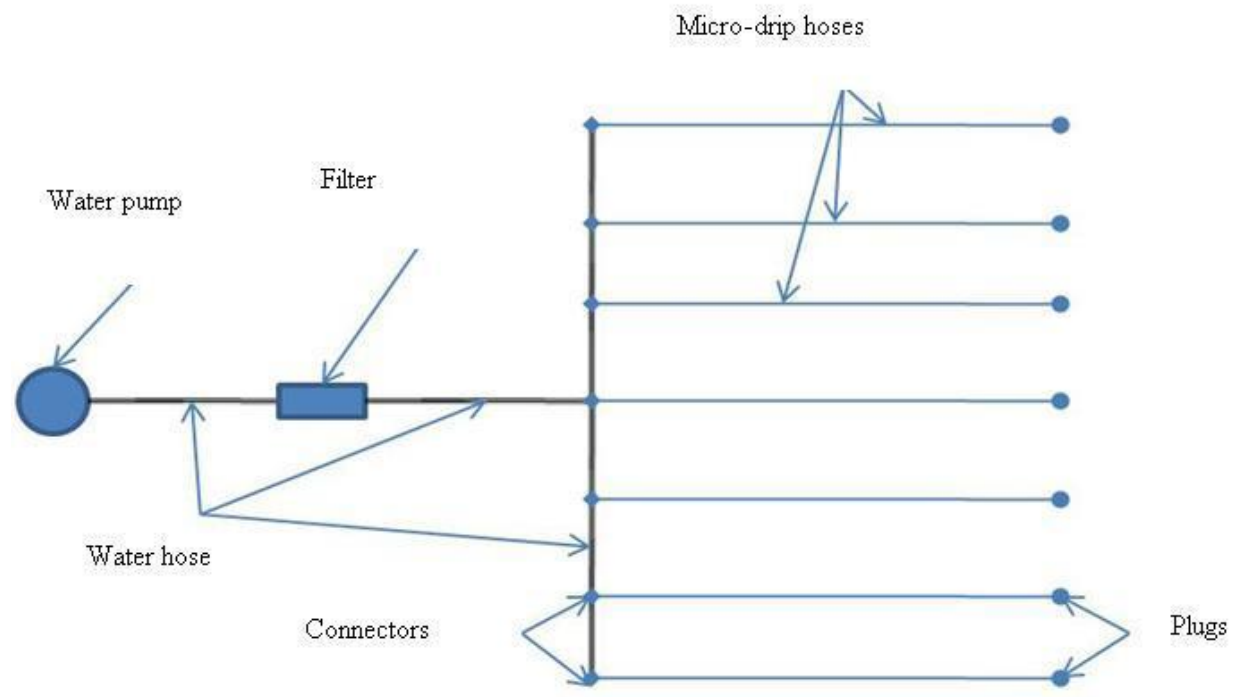

Figure 2.2. Micro-drip installation diagram [18]

Table 2.5. Irrigation accessories needed

\begin{tabular}{|c|c|c|c|}
\hline Vegetables & Plot surface $\left(\mathrm{m}^{2}\right)$ & $\begin{array}{c}\text { The total length of used } \\
\text { hose }(\mathrm{m})\end{array}$ & $\begin{array}{c}\text { Connectors and } \\
\text { Plugs }(\mathrm{pcs})\end{array}$ \\
\hline Potato & 1500 & 3000 & 100 \\
\hline Peas & 460 & 1530 & 153 \\
\hline Zucchini & 40 & 40 & 4 \\
\hline Eggplant & 180 & 300 & 30 \\
\hline Tomato & 100 & 400 & 40 \\
\hline Spinach & 220 & 1100 & 110 \\
\hline Salad & 40 & 200 & 20 \\
\hline Onion & 80 & 200 & 20 \\
\hline Pepper & 20 & 50 & 5 \\
\hline Carrot & 64 & 160 & 16 \\
\hline Beans & 35 & 70 & 7 \\
\hline Cucumber & 25 & 50 & 118 \\
\hline Spices & 236 & 1180 & $\mathbf{6 2 8}$ \\
\hline TOTAL & $\mathbf{3 0 0 0}$ & $\mathbf{8 2 8 0}$ & \\
\hline
\end{tabular}

\subsection{Calculation of water supply pump}

The water pump is chosen taking into account the pressure and the flow needed to supply. [4], [5], [18]. The pump debit is deducted from the maximum monthly consumption, which is in April, with an amount of $113,59 \mathrm{~m}^{3}(\mathrm{Qm})$, resulting the daily water flow:

$$
Q m / 30=3,78 m^{3}(12) \text {, where: Qm- Monthly debit value. }
$$


The pressure required is calculated taking into account the maximum depth at which the pump can work well in the worst case of declining groundwater levels. In most cases the ground water is found at $20 \mathrm{~m}$ depth, during dry periods can descend to a maximum depth of $25 \mathrm{~m}$. At this height it is added the distance between the ground and the upper part of the water basin, which is adopted to be equal to $5 \mathrm{~m}$. Drilling depth HD is $25 \mathrm{~m}$ (drill height), HB is $5 \mathrm{~m}$ (basin height) and HT=25+5=30m (total height).

For the micro drip irrigation systems using photovoltaic energy, on market were imposed Lorentz series pumps with different pressure and flow characteristics. [19]. Given the parameters calculated above, the pump PS 200 is choosen, the LPP00028 model with the following technical characteritcs [17].

Table 2.6. Technical characteristics of pump PS 200 HR 204 (LPP00028) [20]

\begin{tabular}{|c|c|c|}
\hline Characteristics, unit measure & Value & Presentation \\
\hline Pumping capacity [m] & 50 & \\
\hline Debit $\left[\mathrm{m}^{3} / \mathrm{h}\right]$ & 0,8 & \\
\hline Efficiency [\%] & 60 & \\
\hline Solar operation [VCC] & 24 & \\
\hline Open circuit voltage [VCC] & 100 & \\
\hline Solar energy source [Wp] & $80-300$ & \\
\hline
\end{tabular}

Since the flow is $0.8 \mathrm{~m}^{3}$ per hour, results the minimum operating time equal with Qal/qp= $3,78 / 0,8=4,7 \mathrm{~h} /$ day

\subsubsection{Electronic pump controller}

Lorentz pump model LPP00028 is acquired with:

Controller PS200, has the following characteristics: Electrical protection IP 54; 88\% efficiency (motor and controller); Reverse polarity protection; Operating system MPPT (Maximum Power Point Tracking).

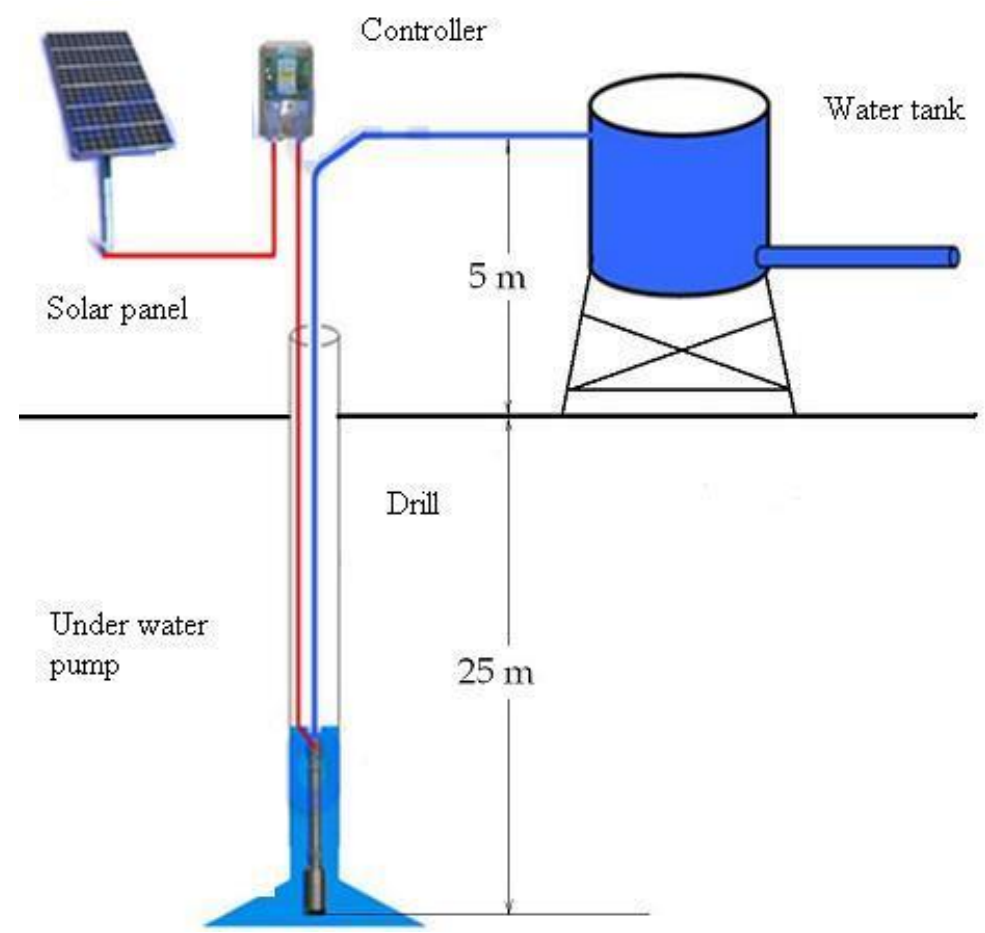

Figure 2.3. Diagram of solar pump type installation used for micro-drip irrigation 


\subsubsection{Solar panel selection}

Given that the maximum height of the pumping flow needs an electrical power of $300 \mathrm{~W}$, there are selected 3 solar panels, polycrystalline photovoltaic, model ET-P636120-120W with the following characteristics:

Table. 2.7. ET-P636120-120WSolar panel characteristics [15]

\begin{tabular}{|l|c|}
\hline Maximum power & $120 \mathrm{~W}$ \\
\hline Voltage & $24 \mathrm{~V}$ \\
\hline Cell number & 36 \\
\hline Operating temperature & $45,3^{\circ}$ \\
\hline Dimensions & $156 \mathrm{~mm} \times 156 \mathrm{~mm}$ \\
\hline
\end{tabular}

Total power delivered by the solar panels is $3 \times 120 \mathrm{~W}=360 \mathrm{~W}$, fulfilling the needs of pump consumption.

\subsubsection{PV installation}

In synthesis the micro-drip irrigation installation powered by a photovoltaic panel is composed from the components presented in table 2.8. The total investment of the installation including VAT is 8192,7 lei (1862 euro).

Table 2.8. Value of inventory objects for the irrigation installation

\begin{tabular}{|c|c|c|c|c|}
\hline No. & Name & $\begin{array}{c}\text { Required } \\
\text { material }(\mathrm{pcs})\end{array}$ & $\begin{array}{c}\text { Unit value } \\
\text { (lei/pcs) }\end{array}$ & Total value (lei) \\
\hline \multicolumn{5}{|c|}{ A. Irrigation installations } \\
\hline 1. & Artery terminator & 5 & 2 & 10 \\
\hline 2. & Row terminator & 628 & 0,5 & 314 \\
\hline 3. & Timer & 1 & 160 & 160 \\
\hline 4. & Voltage stabilizer & 1 & 150 & 150 \\
\hline 5. & Water filter & 2 & 40 & 80 \\
\hline 6. & One way valve & 2 & 25 & 50 \\
\hline 7. & Water tank & 3 & 500 & 500 \\
\hline 8. & Tank support & 3 & 100 & 300 \\
\hline 9. & Valve for artery & 5 & 9,72 & 48,6 \\
\hline 10. & Connectors & 650 & 0,56 & 176 \\
\hline 11. & Curves & 10 & 3,5 & 35 \\
\hline 12. & Solar panel ET P636120-120W & 3 & 1000 & 3000 \\
\hline \multicolumn{4}{|c|}{ Total A. } & 5823,6 \\
\hline \multicolumn{2}{|c|}{ B. Hoses } & $\mathbf{m}$ & lei/m & Total value \\
\hline 13. & Hose for artery & 255 & 0,26 & 58,5 \\
\hline 14. & Hose for rows & 8280 & 0,15 & 1242 \\
\hline \multicolumn{4}{|c|}{ Total B. } & 1300,5 \\
\hline \multicolumn{4}{|c|}{ Installation total value } & 7124,1 \\
\hline \multicolumn{4}{|c|}{ Transportation and installation expenses ( $15 \%$ from installation value) } & 1068,6 \\
\hline \multicolumn{4}{|c|}{ Total value of irrigation installation under assembling } & 8192,7 \\
\hline
\end{tabular}

\section{Conclusions}

1. The study on the concept of a micro-drip irrigation system of a vegetable farm, using solar photovoltaic energy, constitute a constructive approach, of efficient use of renewable energy, in the context of the global promotion of the GREEN ECONOMY concept. 
2. Starting from an example menu typical for the studied geographic area, were calculated daily, monthly and annual vegetable needs for the pension kitchen.

3. From the existing irrigation systems the micro-drip method was selected because of its advantages (low water consumption, easy maintenance, reduction of the number of crop maintenance works), but also beacuse of the possibility of water supply through equipments like solar pumps.

4. Among the studied technical solutions it was selected the Lorentz type solar pump (with brushless motor and high efficiency), powerd by a nomber of 3 photovoltaic panels, with a total power of $360 \mathrm{~W}$. For carrying water up to the plant, there were studied different microdrip systems; the most suitable for the agritouristic vegetable farm was the Gardena system, distributed through 3 pipelines to the entire vegetable farm surface.

5. Integrated analysis of the agritouristic pension concept with a vegetable farm shows the viability of the idea, sustainability of the micro-economic environment model and not least business profitability and positive social impacts.

\section{References}

[1]. Beggs C. - Energy: Management, Supply and Conservation, Clive Beggs, ISBN: 978-0-7506-8670-9, Linacre House, Jordan Hill, Oxford OX2 8DP, UK, 2012;

[1]. Botnari V. - Realizari performante în dezvoltarea durabila a legumiculturii, Institutul de

Genetica si Fiziologie a plantelor al ASM, Editura Corul Pavel, Bucuresti, 2007;

[2]. Constantin E. - Îmbunatatiri funciare, Ed. Cartea Universitara - Bucuresti, 2009;

[3]. Constantin E., Maracineanu Fl. - Rolul îmbunătăţirilor funciare în dezvoltarea rurală durabilă, Ed. Cartea Universitara, Bucuresti, 2005;

[4]. Gruia, R., Gaceu, L.- Conceptul slow - food si filosofia eco-gastronomica, Revista de EcoAgroTurism, Editura Universitatii Transilvania din Brasov, Vol.2, Nr.1, Ian.- mart. 2006, pag. 57-62, ISSN: 1841-642X;

[5]. Savu P. si col. - Îmbunatatiri funciare si irigarea culturilor, Lucrari practice. Ed.Ion Ionescu de la Brad, Iasi, 2005;

[6]. Stan N. - Tehnologia cultivarii legumelor. Vol. II, Universitatea Agronomica Iasi, 1994

[7]. Stan N., Munteanu N., Stan T.-Legumicultura speciala, vol.III, Editura“"Ion Ionescu de la Brad” Iasi, 2003;

[8]. Stan N., Stan T.- Legumicultura generala, vol.I, Editura "Ion Ionescu de la Brad" Iasi, 1999;

[9]. Tom Markvart, L. Castaner - Solar Cells, Materials, Manufacture and Operation, Edited University of Southampton, UK, 2005; doi:10.1016/j.solmat.2005.04.021

Webography:

[10]. http://www.gardena.com - viewed 07.05.2014;

[11]. http://www.builditsolar.com/Projects/WaterPumping/waterpumping.html - viewed 13.06.2014;

[12]. http://www.gradinamea.ro/Calendarul_gradinii_de_legume - viewed 22.06.2014;

[13]. http://www.marcoser.ro/consultanta/calculator-irigare-prin-picurare/ - viewed 25.06.2014;

[14]. http://www.matrixrom.ro- viewed 12.07.2014;

[15]. http://www.solarzone.ro/Dimensionare-Panouri-Solare-Fotovoltaice - viewed 19.07.2014;

[16]. http://www.solarzone.ro/Dimensionare-Sistem-Pompare Lorentz - viewed 26.09.2014;

[17]. http://edis.ifas.ufl.edu/hs388 - viewed 11.09.2014;

[18]. http://solwaterm.com - viewed 21.09.2014;

[19].www.altestore.com\%2Fmmsolar\%2Fothers\%2FLorentz_PS200_Tech_Sheet.pdf\&ei=7vysVLuGHsStUceF gvgO\&usg=AFQjCNH6eK6eMoy5BYt08IMihelTZhn9SA\&bvm=bv.83134100,d.d24\&cad=rja 